\title{
ON THE ROLE OF CREATION AND ORIGIN MYTHS IN THE DEVELOPMENT OF INCA STATE AND RELIGION
}

\section{Tarmo Kulmar}

The article will focus on material on two ancient Peruvian cultures, Tiahuanaco, which according to the Peruvian archaeological periodisation belongs to the sc. Middle Horizon (approx. 700-1100 $\mathrm{AD}$ ) and the Inca culture, called also Tahuantinsuyu after the country of the sc. Late Horizon (I part of the 13th century - 1532).

The ruins of Tiahuanaco city and centre of worship are located on the Altiplano in today's Bolivia, ca $4000 \mathrm{~m}$ from water level, and 21 $\mathrm{km}$ north-east from Lake Titicaca. Tiahuanaco was a capital of a theocratic state governed by priest kings. The state exerted its influence on the development of the whole southern part of Peru in the closing centuries of the last millennium, expanding its influence in a peaceful manner on the vast highland as well as coastal territory. Tiahuanaco, therefore, carried out a pacifistic cultural mission quite different from that of its contemporary militant country of Huari (Wari) in the Peruvian Andes. The religious sources of this period are first and foremost archaeological findings, but to a great extent also the recordings of the 16th century chroniclers.

The religion of Tiahuanaco centred around the cult of a sky and thunder god Viracocha. The deity was generally depicted as having staves in both of his hands and an aureole around his head. The aureole suggests the qualities of a sun god, represented on the bas-relief in the upper part of the famous Sun Gate in Tiahuanaco as well as on ceramic. The staves, on the other hand, suggest Viracocha's distant ancestry from the nearly thousand years older Chavín sky god in North Peru. His attendants were ranking deities in the shapes of cougar, condor, falcon and snake. Viracocha was worshipped as the main god in Huari as well; there his characteristics were apparently more militant. A head of Tiahuanaco state functioned both as a king and the arch-priest and he was revered as Viracocha's embodiment on earth (Kelm 1990: 524-528). 
The chronicle records describe the citizens of Tiahuanaco as "the Viracochas", who were fair-skinned and wore white long robes. Viracocha is also described as a man with fair skin and white beard, attired in a long robe and sandals, wearing a staff, with a cougar lying at his feet. He was a kind and peace-loving god who had also subjected the dreadful jaguar-god to his power. The idea might refer to the Tiahuanaco's peaceful mission among the distant warrior cultures of Peru. According to the legend, however, evil people in short clothes came to the sacred lake and forced Viracocha to leave to north. On his departure they mocked and taunted him for his long robe and lenient disposition. Eventually, he had descended from the highlands to the coast and left over the ocean, promising to return some day (Séjourné 1992: 215, 258).

In 1921 one of the leading researchers of Peruvian cultures from the first part of this century José de la Riva Agüero y Osma, who had also studied the chronicle records as well as linguistic and archaeological data for nearly 25 years, published his "theory of the paleo-Quechuan empire". The theory focused on the hypothesis that Tiahuanaco was originally the cradle and home of the Inca Empire, and the Inca themselves the upper class of the once emigrated Tiahuanaco people. He also argued that the Quechuans, Aymarans and Araucanians had to originate from the same ancient and anthropologically close ancestral nation who spoke a language related to theirs, and was developed to a degree that could influence them, the younger peoples. Riva-Agüero's term for such ancestors was 'paleo-Quechuans' (Busto I s.a.: 186-194).

Even today the Aymarans inhabit the surroundings of Lake Titicaca. They have preserved heritage on their ancient migration and the subjugation of the town people who were driven from the city. Also, the archaeological data supports the idea of the late arrival of the Aymarans. Riva-Agüero speculates that the paleo-Quechuans were now forced to leave among other places for the Cuzco Valley, the later settlement of the Inca. A chronicler informs us that the first king of the Inca Manco Capac came from Tiahuanaco (Vega 1988: 34-37). We also know that the relationship between the Quechuans and the Aymarans could be characterised by a constant feud which might have been caused by the fugitives' anger towards the invaders. Agüero also argues that the affinity of the Quechuan and 
Aymaran languages is due to the existence of a common primal language, possibly the paleo-Quechuan. The archaeological data also confirms the Aymaran immigration. The chullpa's, or the burial towers around Titicaca belonged supposedly to theAymarans; still, the earliest settlers of Tiahuanaco mummified their dead similarly to the Inca, similarities could be found also between the pottery from the golden age of Tiahuanaco and that of the Inca - the ceramic ware of Aymarans is considerably different. The clothing of the Aymarans differed as well, being shorter than the Quechuan dress, which once again supports the legend about the departure of the long-robed Tiahuanacos. Montesinos, the chronicler, informs us that the priest kings of Tiahuanaco, or los amautas as they were called, fled the country trying to save the cult of their own gods (Busto I s.a.: 191). This is another evidence proving that the Inca originated from the upper class who were forced to leave Tiahuanaco by the militant Aymarans, or los piruas. The idea of the Inca having been militant aroused from the new circumstances. The Inca regarded the surroundings of Titicaca as their former home and revered Viracocha as a god who had told them to build the city of Cuzco. Later, the mythology related to Viracocha acquired an important role in the Inca religion.

Thus, we might reason that the founders of the Tiahuanaco culture were the common ancestors of the Quechuans and Aymarans, i.e. the paleo-Quechuans. Presumably, the militant Aymarans crushed Tiahuanaco in the 10th-11th century and forced the majority of the upper class flee northward to the mountain valleys inhabited by other Quechuan kin tribes. The Aymarans could not destroy the powerful civilisation all at once and founded the kingdom of Colla, which in the 15 th century was incorporated into the state of the same Inca who were once driven from their homeland by the Collas. Thus, the hypothesis of Riva-Agüero expanded to a theory which is acknowledged by most of the historians in Peru.

Consequently, the Inca were the genetic and cultural successors of the Tiahuanaco people. According to the archaeological data these Quechuan emigrants arrived at their kin tribes in the Cuzco Valley at the beginning of the 12th century and founded their citystate on the spot. Since 1538 the Inca ruler Pachacutek Yupanqui employed the necessity of defeating the militant Chancas, subju- 
gated other Quechuan city-states and merged them into the empire that reigned the whole of Peru, northern Chile, northern Bolivia and southern Ecuador until the invasion of Spanish conquistadors. The archaeological material for the religion of this period is abundant, and can be compared to the detailed accounts of the 16th-17th century Spanish chronicles (Kauffmann Doig 1991: 78).

The highest ranking deity of the Inca was a celestial supreme being who was first known under the name Viracocha, later also as Pachacamak. Originally, Pachacamak was a sky god of the Lurín Valley in central Peru whose name was later given to the sky god of the Inca. The main god of the Inca state religion was the sun god Inti, who might have been a nature totem of the Quechua or a god of a certain tribe. Another significant deity in the Inca pantheon was the thunder god Illapu who was apparently distinctive from the Tiahuanaco sky god, but was named after a thunder god of the central Peruvian tribes. Viracocha became the culture hero of the Inca who was said to have brought culture to people, then set off to the Pacific and promised to return. (Kulmar 1999: 101-109).

The Inca myths can be divided in two groups - the creation myths and the origin myths.

\section{BRIEFLY ABOUT CREATION MYTHS}

The world was created by Viracocha near Lake Titicaca. After the great deluge or the receding of chaotic floodwaters Viracocha descended to earth and created plants, animals and men to the empty land; he built the city of Tiahuanaco and appointed 4 world rulers of whom Manco Capak became the superior of the Ursa Major world, i.e. the north horizon (Busto II 1981: 7).

\section{BRIEFLY ABOUT ORIGIN MYTHS}

\subsection{Myths about the Ayar brothers}

Four pairs of brothers-sisters created by Viracocha to rule the world left the cave of Mountain Pacaritambo. The whole world was living in an uncivilised and ignorant manner. The newcomers began with 
organising the mankind and divided people into ten large communities. Leading the tribes the brothers set off in search of enough fertile land to sustain themselves. They carried Sunturpaucar, a long staff adorned with colourful feathers, a cage with a sun-bird who could give good advice and other sacred objects in front of them. Making shorter and longer stops they moved towards Cuzco. In the course of the long journey the group became smaller: the rivalling brothers confined one of their companions to a cave, two others wished to break away but were turned into stones. The only surviving brother Ayar Manco a.k.a. Manco Capak accompanied by his sister and wife Mama Ocllo and his brothers' wives, founded the city of World Pole in the name of Viracocha the Creator and Inti the Sun God, and settled there with his people.

\subsection{A myth of Manco Capak and Mama Ocllo}

A long time ago when the world was filled with savages, misery and poverty, a brother and a sister, a married couple Manco Capak and Mama Ocllo left Lake Titicaca. Inti, the sun god had sent them to refine the surrounding peoples, and gave them a golden stick for testing the land for cultivation and then settling in the suitable place. Having found such a place they had to found the state, teach the people how to live proper lives and advocate the worship of the sun god. The journey took a long time. Eventually, in the Cuzco Valley the golden stick disappeared into the ground, and they could start with their mission. Manco Capak taught his people the cultivation and irrigation of land and handicraft, Mama Ocllo taught women spinning, weaving and sewing. The tribe of Manco Capak became to be called by the name of Hanan Cuzco (High Cuzco) and the relatives of Mama Ocllo by the name of Hurin Cuzco (Lower Cuzco). The city and the state was founded in the name of Viracocha and Inti the sun god, also the Sun Temple was built in Cuzco (Busto II 1981: 10-17).

\section{HOW TO INTERPRET THE MYTHS?}

María Rostworowski de Díez Canseco argues that the creation of the Inca state is introduced already in the creation myths (Rostworowski 1988: 31-34). Although originally they seemed to 
function as creation stories about Tiahuanaco culture, they were later apparently customised by the Inca for ideological purposes. The origin of the Inca from the cultural centre around Lake Titicaca has been supported by archaeological data. Editing seems most apparent in accounts of introducing the first legendary ruler Manco Capak, on the one hand, and in dividing the world in four parts, on the other. The Inca state Tahuantinsuyu was also divided into four large provinces ruled by governors.

Recent customisation is even more apparent in the origin myths. Today's scholars argue that both the myth of the Ayar brothers as well as the myth about Manco Capak comes from the same source, whereas the former is older and less edited, the latter more recent and also more edited.

Both versions say that the main character Ayar Manco or Manco Capak had arrived from south and settled in the Cuzco Valley. The part of the story suggests the Tiahuanaco origin of the Inca as well as the flight of the Quechuan elite from the Aymaran invaders.

Leaving Lake Titicaca could serve as a hypothesis that the home of the Inca was located on the Isle of Sun (La Isla del Sol) in Lake Titicaca - according to archaeologists it might have been one of the residences of the upper class Tiahuanaco people. The hypothesis would also explain why Manco Capak was sent by the sun god, as the island became to be called the Isle of Sun only after the sun worship had become the Inca state religion.

In the original version the brothers are sent to refine people by Viracocha, which suggests even the earlier modification of the story from the time when Viracocha was revered as the main god.

The four pairs of brothers-sisters in the original version refers to the four Quechuan tribes who left Tiahuanaco. The married couple consisting of a brother and a sister, in its turn, could be explained by the fact that the Quechuan tribe was exogamous and consisted of two fraterias: in exogamous societies men belong to one frateria and women to another. This could be inferred also from the myth version concerning the division of Cuzco in two - the High and Lower fraterias. 
The disposing of all the other Ayar brothers on the journey in the original version refers either to their settling to different places or the feud between the tribes of Manco and the rest of his brothers.

Different accounts confirm that the Inca led to the Cuzco Valley by Manco Capak had to drive local tribes from the land in order to establish themselves there. People from the droughty Altiplano had to search for humid soils necessary for cultivating corn. Therefore, Manco's golden stick was supposed to point to the land where corn could be grown. For settling in the new place a fight was put up, and we all know the outcome of the attack. In fact, chronicler Sarmiento do Gamboa's expression "gloomy and fertile" might refer to the gory battles fought for the fertile valley.

Both versions end with the account of building the city by Manco in the name of Viracocha the Creator and Inti the sun god. The former was originally the sky god of the ancient Tiahuanaco people, whose cult was later abandoned. Inti, on the other hand, was the tribal deity of the Inca who later became the highest ranking god in the pantheon. The fact that in the later version the instigator of refining people was Inti, and also that a temple to the sun god was first erected in Cuzco suggests that the journey from Altiplano to the Cuzco Valley must have taken a long time, at least a couple of centuries (archaeological data supports the fact that Tiachuanaco was destroyed by the Aymarans in the 10th century, and the Inca reached the Cuzco Valley at the end of the 12th century). Thus, during this period one deity was substituted for another: Viracocha became deus otiosus, Inti, on the other hand became so popular that the first temple was built for him.

As I mentioned before, the supreme god was given a new name Pachacamak. From then on, Viracocha was associated with the myth of a culture hero, because:

1. the fact that the Tiachuanaco people had spread the cult of Viracocha widely in Peru was never forgotten;

2. the sc. civilisational emigration of the Inca really did take place;

3 . the abandoning of the sky god's cult is reflected by the account of Viracocha's set-off to the ocean;

4. Viracocha's promise to return refers to the fact that the sky god's cult never really disappeared, and in greatest troubles the Inca 
still addressed their sky god, as is common for deus otiosus (Kulmar 1999: 101-109).

Thus, Manco Capak who supposedly ruled the Inca at the time of their arrival at the Cuzco Valley, became the first half-legendary ruler of the country and started the official Inca dynasty. Certainly, he was nothing more than a tribal chief - it took another two centuries for the Inca civilisation to reach its golden era under the rule of the first emperor Pachacutek Yupanqui (Busto II 1981: 22).

The founding of city in the name of two gods could be interpreted in a manner uniquely provident and theocratic for the history of the Andean state Tahuantinsuyu: the supreme god Viracocha had provided that Manco's tribe will rule the world, and Manco started to carry it out at the will and guidance of Inti, the sun god. Thus, the civilisational mission of the Inca found a theological explanation as well (see also Soriano 1990: 483-499).

Finally, these origin myths also reveal the ethnocentric world-view of the Quechuans: the Inca believed in the inherent superiority and wisdom of their own people, thinking they were destined to refine the mankind whether other peoples accepted it or not. That could be inferred also from the names of the country and its capital. The name of the Inca empire Tahuantinsuyu stands for "the country of four points of compass" (Vega 1988: 17). Most chroniclers (except for Sarmiento) argue that Cuzco means "pole" (Busto II 1981: 8), i.e. the centre of the world or the world pole.

The analysis of the history and society of the Inca state has confirmed that it was the first and only totalitarian state on theAmerican continent and Pre-Columbian America (Kulmar 1989: 74-76; Soriano 1990: 483-499). The ethnocentric and imperialist origin myth formed the ideological foundation for establishing such a scheme of society, determining also the mentality of its nation by education and in everyday life.

Thus, the Inca built their historical studies and regulations on the ancient Tiahuanaco myths, having customised them according to their own need. 


\section{References}

Busto I = Busto Duthurburu, José Antonio del I s.a. Perú PreIncaico. Lima: Editorial Universo S.A.

Busto II = Busto Duthurburu, José Antonio del II 1981. Perú Incaico. Lima: Libreria Studium S.A.

Kauffmann Doig, Federico 1991. Introducción al Perú antiguo. Lima: Editores Kompaktos.

Kelm, Antje 1990. Grundzüge der Religionen des zentralen Andenraumes. Altamerikanistik: Eine Einführung in die Hochkulturen Mittel- und Südamerikas. Herausgegeben von Ulrich Köhler. Berlin: Dietrich Reimer Verlag.

Kulmar, Tarmo 1989. Märkmeid totalitaarsest riigist. Vikerkaar, nr. 2.

Kulmar, Tarmo 1999. Zum Problem des Kulturheros in der InkaReligion. Mitteilungen für Anthropologie und Religionsgeschichte. B. 12, 1997. Münster: Ugarit-Verlag.

Rostworowski de Díez Canseco, María 1988. História del Tahuantinsuyu. Lima: Instituto de Estudios Peruanos.

Séjourné, Laurette 1992.Altamerikanische Kulturen. Frankfurt am Main: Fischer Verlag.

Soriano, Waldemar Espinoza 1990. Los Incas. Economía, sociedad y Estado en la era del Tahuantinsuyo. Lima: Amaru Editores.

Vega, Inca Garcilaso de la 1988. Comentarios reales de los Incas. T. 1. Lima: Editorial Mercurio S.A. 